\title{
Novel I-Imidazoline Agonist S43126 Augment Insulin Secretion in Min6 Cells
}

\author{
Jerusalem Tesfai ${ }^{1}$, Louis Crane ${ }^{2}$, Genevieve Baziard-Mouysset ${ }^{2}$ and Lincoln P. Edwards ${ }^{3 *}$
}

${ }^{1}$ Department of Biochemistry, Loma Linda University School of Medicine, Loma Linda, CA, USA

${ }^{2}$ Laboratoire de Chimie Pharmaceutique, Universite Paul Sabatier, Faculté de Pharmacie, USA

${ }^{3}$ Center for Dental Research, School of Dentistry and School of Medicine, Loma Linda University, Loma Linda, CA, USA

\begin{abstract}
The I-imidazoline receptor is a novel drug target for hypertension and insulin resistance which are major disorders associated with Type II diabetes. In the present study, we examined the effects of a novel imidazoline agonist S43126 on calcium fluxes and insulin secretion from Min6 $\beta$-cells. We also examined the effects of S43126 on the induction of IRAS, and phosphorylation of components in the I-imidazoline signaling pathways, namely ERK and PKB. Min $6 \beta$-cells were treated with varying doses of $S 43126\left[10^{-8} \mathrm{M}\right.$ to $\left.10^{-5} \mathrm{M}\right]$ for various time $(5-60 \mathrm{mins})$. S43126 at higher dose $\left[10^{-5} \mathrm{M}\right]$ stimulated insulin secretion under elevated glucose concentration compared to basal. In addition, insulin secretion and $\mathrm{Ca}^{2+}$ influx mediated by $\mathrm{S} 43126\left[10^{-5} \mathrm{M}\right]$ were decreased following co-treatment with efaroxan $\left(\mathrm{I}_{1}\right.$-antagonist) and nifedipine (L-type voltage-gated $\mathrm{Ca}^{2+}$-channel blocker) at various times (5-60mins). Furthermore, S43126 at [10 $\left.{ }^{5} \mathrm{M}\right]$ increased $\mathrm{Ca}^{2+}$ oscillation, $\left[\mathrm{Ca}^{2+}\right]$ and ${ }^{45} \mathrm{Ca}^{2+}$ uptake in a time and dose-dependent manner. Moreover, Western blot analysis of treated samples showed that $\$ 43126$ caused an increased protein expression of IRAS as well as phosphorylation of both ERK1/2 and PKB in a concentration-dependent manner. We conclude that S43126 exerts its insulinotropic effect in a glucose dependent manner by a mechanism involving L-type calcium channels and imidazoline $\mathrm{I}_{1}$-receptors
\end{abstract}

\section{Introduction}

Insulin resistance and hypertension are commonly associated with metabolic syndrome, which affects over 75 million Americans, and type 2 diabetes which affects over 18 million Americans [1]. Pharmacologic treatment of many type 2 diabetic patients requires separate agents for treating hyperglycemia, and hypertension. This results in patients having to take multiple medications, which negatively impact patient compliance and increases the risk for drug interaction. In response to this growing health care problem, compounds that have the ability to counter both hyperglycemia and hypertension would positively impact compliance and be an asset to patients.

Pharmacologic criteria have defined three main types of imidazoline receptors: the $\mathrm{I}_{1}$ subtype is labeled by $\left[{ }^{3} \mathrm{H}\right]$ clonidine and the $\mathrm{I}_{2}$ subtype is labeled by $\left[{ }^{3} \mathrm{H}\right]$ idazoxan $[2,3]$. A third pharmacologically distinct entity, the $\mathrm{I}_{3}$ subtype, is found in the pancreas and is involved in regulation of insulin secretion [4]. Functionally, $\mathrm{I}_{2}$-imidazoline sites seem to play a role in depression as the density of $\mathrm{I}_{2}$-sites were altered in suicide/ depressive patients and the $\mathrm{I}_{2}$-selective compound 2-(2-benzofuranyl)2-imidazoline (2-BFI) demonstrated antidepressant-like effects in mice according to the tail suspension test and the forced swim test [5]. The $\mathrm{I}_{2}$-site is also an emerging drug target for pain treatment [6] and $\mathrm{I}_{2}$-agonists have been shown to enhance the antinociceptive effects of opioids [7]. There is an emerging role for $\mathrm{I}_{2}$-agonists in the regulation of glucose homeostasis. Cerebral injections of agmatine reduced plasma glucose levels in streptozotocin-induced diabetic (STZ-diabetic) rats by a mechanism not involving insulin secretion but activation of $\mathrm{I}_{2}$-imidazoline receptors [8]. It was subsequently shown that peripheral administration of agmatine caused activation of $\mathrm{I}_{2}$ receptors in the adrenal medulla to enhance secretion of $\beta$-endorphins, leading to activation of $\mu$-opioid receptors, and lower glucose levels [9]. Additionally it was shown that in rats where insulin resistance was induced by a high fructose diet, agmatine $(1 \mathrm{mg} / \mathrm{kg})$ ameliorated the insulin resistance by a mechanism involving $\mathrm{I}_{2}$-imidazoline receptors [10].

Imidazoline compounds, which are agonists at the $\mathrm{I}_{1}$-imidazoline receptor $\left(\mathrm{I}_{1} \mathrm{R}\right)$ present in the rostral ventrolateral medulla (RVLM) region of brain $[11,12]$ act centrally to lower blood pressure. Clinical and basic findings also indicate a role for $\mathrm{I}_{1}$-imidazoline agonists in the treatment of insulin resistance and diabetics with hypertension $[13,14]$

Several studies have shown that compounds containing the imidazoline moiety are potent stimulators of insulin secretion from pancreatic $\beta$-cells [15-19]. The mechanisms by which imidazoline compounds promote insulin secretion have not been fully elucidated. Classical imidazoline compounds mimic the actions of sulfonylurea drugs and interact directly with the pore-forming component (Kir6.2) of the ATP-sensitive potassium $\left(\mathrm{K}_{\mathrm{ATP}}\right)$ channel to promote channel closure, membrane depolarization, $\mathrm{Ca}^{2+}$ influx and insulin secretion $[15,17,20,21]$. These agents also have a direct effect on exocytosis. Other imidazoline compounds have been shown to have no effect on the $\mathrm{K}_{\text {ATP }}$ channel, but exert their insulinotropic effects only if glucose concentration is elevated [18]. Some agents show a dependence on protein kinase $\mathrm{A}$ and $\mathrm{C}$ to exert their insulinotropic effects [18]

We have previously shown that $\mathrm{S} 43126\left(\mathrm{pK}_{\mathrm{i}} \mathrm{I}_{1}=7.46, \mathrm{pK}_{\mathrm{i}} \mathrm{I}_{2}=8.28, \mathrm{pK}\right.$ $\alpha_{1}<5$ and $\left.\mathrm{pK}_{\mathrm{i}} \alpha_{2}<5\right)$ a novel imidazoline compound with close binding affinities for both $\mathrm{I}_{1}$ and $\mathrm{I}_{2}$ imidazoline binding sites [22], lowers blood pressure when injected into the RVLM of spontaneously hypertensive rats. This compound does not contract rat tail arterial strips suggesting

*Corresponding author: Lincoln P. Edwards, Department of Physiology \& Pharmacology, 11041 Campus Street, Risley Hall 106, Loma Linda University School of Medicine, Loma Linda, CA, USA, Tel: (909) 558-4000 ext 42923; Fax: (909) 558-0119; E-mail: Ipedwards@llu.edu

Received February 15, 2012; Accepted April 20, 2012; Published April 25, 2012

Citation: Tesfai J, Crane L, Baziard-Mouysset G, Edwards LP (2012) Novel I Imidazoline Agonist S43126 Augment Insulin Secretion in Min6 Cells. J Diabetes Metab 3:183. doi:10.4172/2155-6156.1000183

Copyright: ( 2012 Tesfai J, et al. This is an open-access article distributed unde the terms of the Creative Commons Attribution License, which permits unrestricted use, distribution, and reproduction in any medium, provided the original author and source are credited. 
that it is inactive at alpha adrenergic receptors [23]. In this study we describe the effects of S43126 on calcium fluxes, insulin secretion and glucose uptake. Imidazoline compounds may prove useful in treating diabetics with hypertension

\section{Materials and Methods}

\section{Antibodies and reagents}

Primary antibodies used were IRAS, $\beta$-actin, p44/42 MAP kinase, phospho-p44/42 MAP kinase (Thr-202/Tyr-204), Akt, phosphoAkt (Ser473) antibody diluted 1:1000, which were detected using a secondary antibody (HRP linked anti-rabbit IgG), diluted 1:2000 and enhanced chemiluminescence (ECL, Amersham Pharmacia Biotech). Treated cells were lysed and aliquots were subjected to western blotting using appropriate antibodies.

\section{Cell culture and drug treatment}

Min6 $\beta$-cells were cultured in DMEM (Cellgro) supplemented with $15 \% \mathrm{FBS}, 5 \mathrm{ml}$ penicillin/streptomycin solution (Sigma), $1 \mu \mathrm{L}$ $\beta$-mercaptoethanol (Sigma) and maintained in the presence of $5 \%$ $\mathrm{CO}_{2}$ at $37^{\circ} \mathrm{C}$. Min6 $\beta$-cells were treated with varying doses of $\mathrm{S} 43126$ $\left[10^{-5} \mathrm{M}-10^{-8} \mathrm{M}\right]$ for different times, in the presence or absence of $\mathrm{I}_{1}$ imidazoline receptor blocker efaroxan $[100 \mu \mathrm{M}]$ or L-type calcium channel blocker nifedipine $[10 \mu \mathrm{M}]$.

\section{Single-cell microfluorimetry}

Min6 $\beta$-cells were seeded on $25 \mathrm{~mm}$ glass coverslips in $35 \mathrm{~mm}$ plastic dishes. Twenty-four hours before imaging, culture medium was replaced with serum free medium. On the day of the experiment, culture medium was removed; cells were washed twice with KrebsRinger bicarbonate (KRB) buffer, $\mathrm{pH} 7.5$, and containing $2.8 \mathrm{mM}$ glucose. Washed cells were incubated with $\mathrm{KRB} /$ glucose for 2 hours at $37^{\circ} \mathrm{C}, 5 \% \mathrm{CO}_{2}$ In preparation for imaging, cells grown on the coverslip were loaded with $5 \mathrm{ul}$ of $\mathrm{Ca}^{2+}$ Fluorophore, Fura2/AM for 45 mins at room temperature. The coverslips were rinsed in KRB buffers and placed in a $300 \mu \mathrm{l}$ steel chamber attached to the stage of a Nikon inverted microscope (Nikon Instruments, Tokyo, Japan). A low pressure, rapid super fusion system $(3 \mathrm{ml} / \mathrm{min})$ was used to change solutions (i.e. S43126, glucose and KRB buffers) in the bath chamber. Ratios of $510 \mathrm{~nm}$ emission at $340 \mathrm{~nm}$ vs. $380 \mathrm{~nm}$ excitation wavelengths were acquired every second by photometric Cool Snap 12-bit digital camera. To facilitate comparison between experiments, data are expressed as $340 / 380$-nm ratios normalized to the baseline ratio [24].

\section{${ }^{45} \mathrm{Ca}^{2+}$ influx}

${ }^{45} \mathrm{Ca}$ influx was determined by a modification of the methods of Edwards et al. and Brigand et al. [25,26]. Min6 $\beta$-cell in 6-well plates were treated as above but on the day of the experiment, cells were preincubated for $10 \mathrm{~min}$ at $37^{\circ} \mathrm{C}, 5 \% \mathrm{CO}_{2}$ in $\mathrm{KRB}$. The preincubation solution was then replaced with $\mathrm{KRB}$ containing $3 \mathrm{uCi} / \mathrm{ml}{ }^{45} \mathrm{CaCl}_{2}$, in the presence or absence of $S 43126\left[10^{-5} \mathrm{M}\right]$, efaroxan $[100 \mu \mathrm{M}]$ or nifedipine $[10 \mu \mathrm{M}]$ for various times $(0-30$ mins). Treated cells were quickly washed five times with ice-cold saline and then solubilized in $1 \mathrm{ml} \mathrm{KRB}$ containing $0.1 \%$ Triton for 4 hours at room temperature. Aliquots $(200 \mu \mathrm{l})$ of the solution were then assayed for ${ }^{45} \mathrm{Ca}^{2+}$ content after the addition of $5 \mathrm{ml}$ liquid scintillation medium (Perkin Elmer). Protein concentrations were determined using the BioRad DC Protein assay reagents (BioRad, Hercules, CA).

\section{Insulin secretion}

Monolayers of Min6 $\beta$-cells were seeded 3 days before each series of studies in 24 -well plates at a density of 500,000 cells per well. 12 hours before each experiment, the culture medium was replaced with serum free medium. On the day of the experiment, the cells were washed twice with KRB buffer, $\mathrm{pH} 7.5$, containing $0.1 \%$ BSA (KRB-BSA). Cells were then preincubated for $2 \mathrm{hrs}$ in KRB-BSA containing $2.8 \mathrm{mM}$ glucose at $37^{\circ} \mathrm{C}, 5 \% \mathrm{CO}_{2}$ followed by incubated for 2 hours in KRB-BSA containing various concentration of effectors (S43126, efaroxan and nifedipine) and glucose $(2.8 \mathrm{mM}$ or $16.7 \mathrm{mM})$ [13]. After incubation, the medium was collected, centrifuged at $600 \mathrm{X} \mathrm{g}$ for $10 \mathrm{mins}$ and stored at $-20^{\circ} \mathrm{C}$. Insulin release was measured using Mercodia ultrasensitive mouse insulin enzyme-linked immunosorbent assay (ELISA) kit (Mercodia $A B$, Uppsala, Sweden). Protein concentrations were determined using the BioRad DC Protein assay reagents (BioRad, Hercules, CA).

\section{Statistical analysis}

Data was analyzed using two-way analysis of variance (ANOVA) or Tukey's test for pair-wise multiple comparisons to identify significant differences $(\mathrm{P}>0.05)$ between individual samples. Percent blockade was calculated using the formula $\%$ blockade $=(\mathrm{S}-[\mathrm{S}+\mathrm{N}]) /(\mathrm{S}-$ baseline $)$ * 100 (Figure 3 and 4).

\section{Results}

\section{Effects of S43126 on insulin secretion}

We examined the ability of $S 43126\left[10^{-7} \mathrm{M}-10^{-5} \mathrm{M}\right]$ to induce insulin secretion directly from Min6 $\beta$-cells at various times (5-60mins) under conditions of basal glucose $(2.8 \mathrm{mM})$ and high glucose $(16.7 \mathrm{mM})$. S43126, a novel $\mathrm{I}_{1}$-imidazoline agonist (Figure 1), induced a dosedependent release of insulin at 5 mins, 10 mins and 30 mins under conditions of basal glucose (Figure 2A), and under high glucose (Figure 2B). At 5 mins and 10 mins, the amount of insulin release caused by a particular dose of $\$ 43126$ was greater under conditions of high glucose than at basal glucose. Under conditions of basal glucose, the maximal release of insulin was 2.3 fold, seen at 5 mins of treatment with $10^{-5} \mathrm{M}$ S43126. Under conditions of high glucose, the maximal release of insulin was 3.1 fold, seen at 5 mins of treatment with $10^{-5} \mathrm{M} \mathrm{S43126.}$ Relative insulin secretion decreased with time following stimulation under basal and high glucose.

In order to evaluate the role of $\mathrm{I}_{1}$-imidazoline receptor and L-type calcium channel in the insulinotropic effect of S43126, we treated Min 6 cells with $S 43126\left[10^{-5} \mathrm{M}\right]$ in the presence or absence of either efaroxan $[100 \mu \mathrm{M}]\left(\mathrm{I}_{1}\right.$-antagonist) or nifedipine $[10 \mu \mathrm{M}]$ (L-type calcium channel blocker) for various times $(5-60 \mathrm{mins})$. We used $\mathrm{S} 43126\left[10^{-5} \mathrm{M}\right]$ as this dose produced the maximum release of insulin in our previous study. Under conditions of basal glucose, efaroxan caused $92 \%, 50 \%, 166 \%$, and $85 \%$ inhibition of insulin release by $\$ 43126$ at 5 mins, 10 mins, 30 mins, and 60 mins respectively (Figure $3 \mathrm{~A}$ ). Efaroxan by itself caused release of insulin under both basal and high glucose conditions. Under

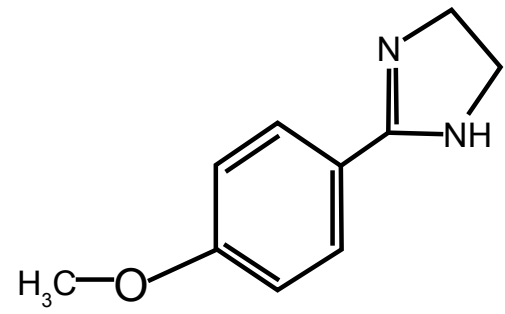

Figure 1: Chemical Structure of the Novel Imidazoline Compound, S43126. 
Citation: Tesfai J, Crane L, Baziard-Mouysset G, Edwards LP (2012) Novel I-Imidazoline Agonist S43126 Augment Insulin Secretion in Min6 Cells. J Diabetes Metab 3:183. doi:10.4172/2155-6156.1000183

conditions of high glucose, efaroxan caused a greater than $89 \%, 100 \%$, $93 \%, 100 \%$ inhibition of insulin release by S43126 at 5 mins, 10 mins, 30 mins and 60 mins respectively (Figure 3B).

Co-treatment of Min 6 cells with nifedipine $[10 \mu \mathrm{M}]$, caused an approximately $73 \%, 63 \%, 91 \%$ and $>80 \%$ reduction in insulin release at $5 \mathrm{mins}, 10 \mathrm{mins}, 30 \mathrm{mins}$ and 60 mins respectively under basal glucose conditions (Figure 4A). Inhibition of insulin release by nifedipine was more dramatic under high glucose conditions. Nifedipine caused a greater than $90 \%$ reduction in insulin release at all time points (Figure $4 B)$.

\section{Effects of S43126 on $\left[\mathrm{Ca}^{2+}\right]_{\text {i }}$}

When Min6 $\beta$-cells were incubated with S43126 $\left[10^{-8} \mathrm{M}-10^{-5} \mathrm{M}\right]$ in the presence of $2.8 \mathrm{mM}$ glucose, $\mathrm{S} 43126$ caused a dose-dependent increase in $\left[\mathrm{Ca}^{2+}\right]_{i}$ which was first observed at $\left[10^{-6} \mathrm{M}\right]$ of $\mathrm{S} 43126$ (Figure 5A). The amplitude of the calcium oscillations evoked by $\$ 43126$ at $2.8 \mathrm{mM}$ glucose were less than those produced by $16.7 \mathrm{mM}$ glucose, but greater than control, at higher doses. The increase in $\left[\mathrm{Ca}^{2+}\right]_{i}$ caused by
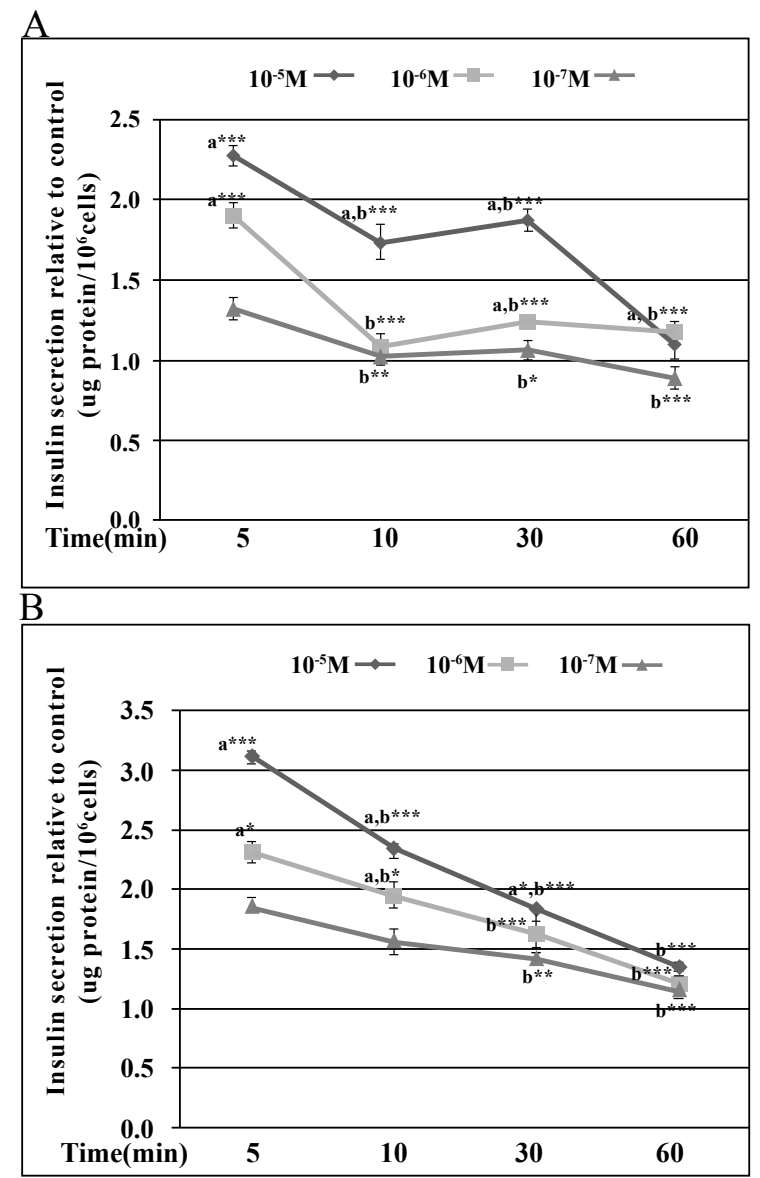

Figure 2: Stimulatory effects of S43126 on insulin release from Min6 cells. $\mathrm{S} 43126\left[10^{-5} \mathrm{M}\right]$ at $5 \mathrm{mins}$ induced the highest insulin release $(2.3$ fold $)$ and 3.1 fold under conditions of (A) low glucose ( $2.8 \mathrm{mM}$ ) and $(B)$ high glucose $(16.8 \mathrm{mM})$ respectively, relative to control. (A) Data are presented as mean percent change $+/$ - standard error from three separate experiments run in duplicate. $\left(\boldsymbol{a}={ }^{* * *} \mathrm{p}<0.001\right.$ same time point, compared to $\left[10^{-7} \mathrm{M}\right]$ and $\boldsymbol{b}=$ ${ }^{* * *} p<0.001$ same dose, different time compared to 5 mins, ANOVA) (B) Data are presented as mean percent change $+/$ - standard error from three separate experiments run in duplicate. $\left(a={ }^{* *} p<0.01,{ }^{* * *} p<0.001\right.$ same time point, compared to $\left[10^{-7} \mathrm{M}\right] \boldsymbol{b}={ }^{* *} p<0.01,{ }^{* * *} p<0.001$ same dose, different time compared to 5 mins, two-way ANOVA).
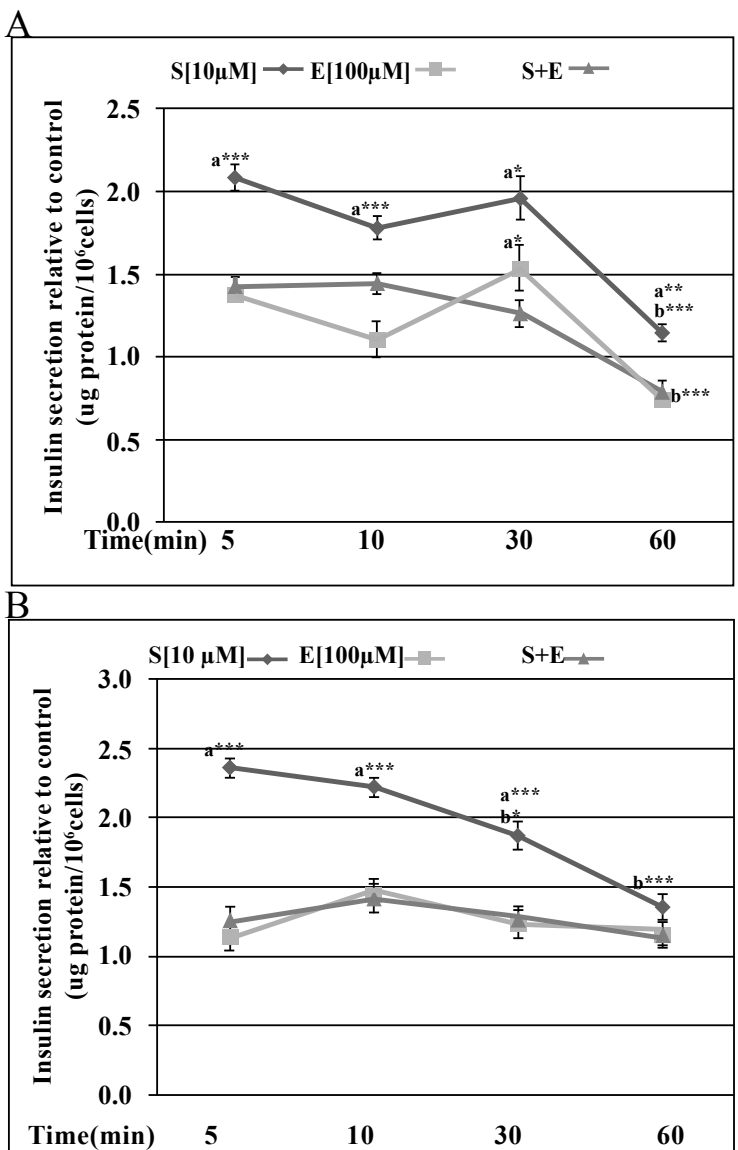

Figure 3: Effects of Efaroxan (E) on S43126(S)-induced insulin release. $\mathrm{I}$-imidazoline receptor antagonist Efaroxan) $[100 \mu \mathrm{M}]$ attenuated the insulinotropic response of Min6 cells to S41326 under (2A) low and (2B) high glucose. (2A) Data are presented as mean percent change $+/$ - standard error from three separate experiments run in duplicate. $\left(a={ }^{* *} p<0.01,{ }^{* * *} p<0.001\right.$ same time point, compared to $\mathbf{E}$ and $\boldsymbol{b}={ }^{* \star *} \mathrm{p}<0.001$ same dose, different time compared to 5 mins, ANOVA). (2B) Data are presented as mean percent change $+/$ - standard error from three separate experiments run in duplicate. $\left(\boldsymbol{a}={ }^{* * *} p<0.001\right.$ same time point, compared to $\mathbf{E}$ and $\boldsymbol{b}={ }^{* * *} p<$ 0.001 same dose, different time compared to 5 mins, two-way ANOVA).

S43126 $\left[10^{-5} \mathrm{M}\right]$ and $2.8 \mathrm{mM}$ glucose were similar at $1 \mathrm{~min}$, however S43126 $\left[10^{-5} \mathrm{M}\right]$ caused a gradual increase in $\left[\mathrm{Ca}^{2+}\right]_{\mathrm{i}}$ up to $5 \mathrm{~min}$ followed by a slight decline. Under conditions of basal glucose, $\left[\mathrm{Ca}^{2+}\right]_{i}$ gradually declined with time. The temporal response of $\left[\mathrm{Ca}^{2+}\right]_{\mathrm{i}}$ to high glucose, mimic that of S43126 $\left[10^{-5} \mathrm{M}\right]$ but with higher levels of $\left[\mathrm{Ca}^{2+}\right]_{i}$. (Figure $5 B)$.

\section{Effects of S43126 on ${ }^{45} \mathrm{Ca}^{2+}$ uptake}

Min 6 cells were also incubated with ${ }^{45} \mathrm{Ca}^{2+}$ alone or in combination with $S 43126\left[10^{-5} \mathrm{M}\right]$ at various times $(0-60 \mathrm{mins})$. There was a timedependent increase in ${ }^{45} \mathrm{Ca}^{2+}$ influx up to $5 \mathrm{mins}$, followed by a decline at 10 mins and then a plateau between 30- 60 mins (Figure 6A). The maximum influx of greater than 3 fold was seen at 5 mins.

Since $\mathrm{S} 43126\left[10^{-5} \mathrm{M}\right]$ provoked marked ${ }^{45} \mathrm{Ca}^{2+}$ influx at 5 mins, we co-treated cells with $S 43126\left[10^{-5} \mathrm{M}\right]$ in the presence or absence of either efaroxan $(10 \mu \mathrm{M})$ or nifedipine $(10 \mu \mathrm{M})$ with the aim of determining whether $\mathrm{I}_{1}$-imidazoline receptor or L-type calcium channels mediated the observed ${ }^{45} \mathrm{Ca}^{2+}$ influx into Min 6 cells. S43126 increased ${ }^{45} \mathrm{Ca}^{2+}$ influx by 4 fold and this increase was blocked by efaroxan (Figure 6B). 
Citation: Tesfai J, Crane L, Baziard-Mouysset G, Edwards LP (2012) Novel I-Imidazoline Agonist S43126 Augment Insulin Secretion in Min6 Cells. J Diabetes Metab 3:183. doi:10.4172/2155-6156.1000183

Page 4 of 7
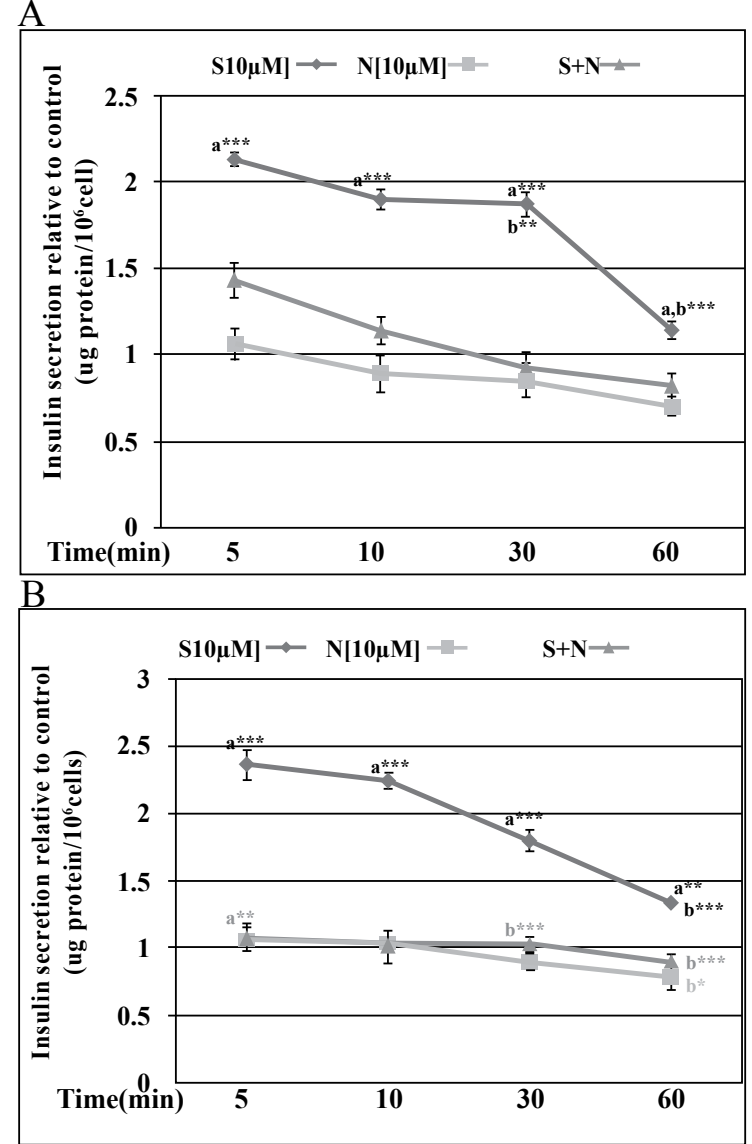

Figure 4: Effects of Nifedipine (N) on S43126(S)-induced insulin release. Voltage-gated L-type calcium channel blocker nifedipine [10 $\mu \mathrm{M}]$ attenuated the insulinotropic response of Min6 cells to S43126 under (3A) low and (3B) high glucose. (3A) Data are presented as mean percent change $+/$ - standard error from three separate experiments run in duplicate. $\left(a={ }^{*} p<0.05,{ }^{* * *} p<\right.$ 0.001 same time point, compared to $\mathbf{N}$ and $\boldsymbol{b}={ }^{* *} p<0.01,{ }^{* * *} p<0.001$ same dose, different time compared to 5 mins, ANOVA). (3B) Data are presented as mean percent change $+/$ - standard error from three separate experiments run in duplicate. $\left(\boldsymbol{a}={ }^{* * *} \mathrm{p}<0.001\right.$ same time point, compared to $\mathbf{N}$ and $\boldsymbol{b}=$ ${ }^{* *} p<0.01,{ }^{* * *} p<0.001$ same dose, different time compared to 5 mins, twoway ANOVA).

In addition, nifedipine, a blocker of L-type calcium channels, reduced ${ }^{45} \mathrm{Ca}^{2+}$ influx by $\mathrm{S} 43126$ to near basal levels (Figure $6 \mathrm{~B}$ ).

\section{Effects of $\$ 43126$ on ERK1/2, PKB phosphorylation and IRAS protein expression}

S43126 $\left[10^{-7} \mathrm{M}-10^{-5} \mathrm{M}\right]$ induce IRAS protein expression in a dosedependent manner (Figure 7A). S43126 $\left[10^{-7} \mathrm{M}-10^{-5} \mathrm{M}\right]$ also cause a 3 -fold increase in ERK1/2 phosphorylation (Figure 7B) and a 2-fold increase in PKB phosphorylation (Figure 7C). ERK1/2 and PKB are components of both the insulin and imidazoline receptor signaling pathways.

\section{Discussion}

Compounds that have the ability to treat both hypertension and insulin resistance would greatly improve compliance among patients. The novel imidazoline compound S43126 has been shown previously to lower blood pressure in rats following injection into the RVLM, but did not contract rat tail artery [23]. We therefore wanted to determine whether S43126 also had the ability to affect glucose homeostasis. Treatment of Min6 $\beta$-cells with S43126 caused a dose-dependent increase in insulin secretion at 5 mins, 10 mins and 30 mins under conditions of basal glucose (Figure 2A), and under high glucose (Figure2B). This increase in insulin secretion was modest, but glucosedependent, with S43126 causing a greater insulin release at higher concentrations of glucose at 5 mins and 10 mins. This is in contrast to sulfonylurea drugs which demonstrate a strong insulinotropic effect at basal glucose concentrations. Agents that stimulate robust insulin secretion at basal levels of glucose are more likely to cause hypoglycemia in patients [27]. A more desirable therapeutic outcome would be achieved by agents such as $\$ 43126$ that augment glucoseinduced insulin secretion.

The effect of imidazoline compounds on glucose homeostasis is mediated by all three subtypes of imidazoline receptors. $\mathrm{I}_{1}$-imidazoline and $\mathrm{I}_{3}$-imidazoline agonists mediate insulin release, while $\mathrm{I}_{2}$-imidazoline agonists mediate insulin sensitization. It was shown previously that cerebral injections of agmatine caused a decrease in plasma glucose in STZ-diabetic rats, but plasma levels of glucose and insulin were not affected in normal rats [8]. This suggested that agmatine was acting through a non-insulin dependent mechanism, and did not cause insulin release in normal rats. The effects of agmatine on glucose levels were attenuated in a dose-dependent manner with the $\mathrm{I}_{2}$-imidazoline receptor blocker BU-224. It was subsequently shown that peripheral injections of agmatine into STZ-diabetic rats also lowered plasma glucose in a dose-dependent manner [9]. The proposed mechanism for

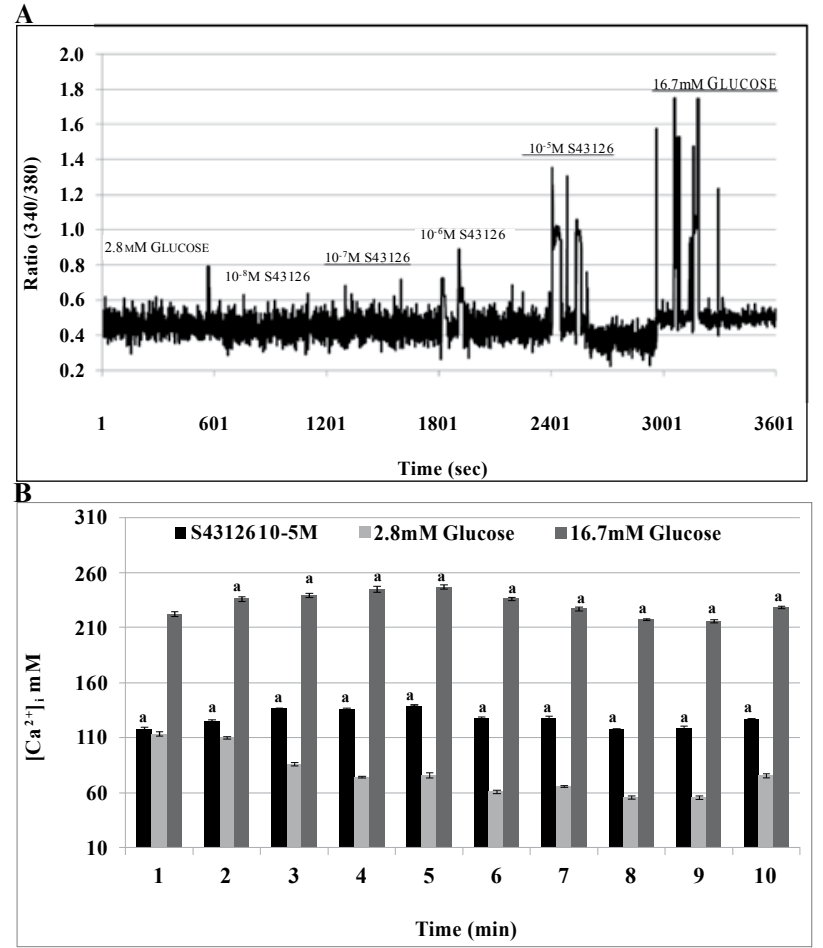

Figure 5: Effects of S43126 on $\mathrm{Ca}^{2+}$ oscillations. S43126 evoked a dosedependent increase in cytosolic $\mathrm{Ca}^{2+}$ under (3A) conditions of basal glucose $(2.8 \mathrm{mM})$. (B) S43126 $\left[10^{-5} \mathrm{M}\right]$ caused an increase in $\left[\mathrm{Ca}^{2+}\right]$ that was greater than the influx caused by $2.8 \mathrm{mM}$ glucose but less than the influx caused by $16.7 \mathrm{mM}$ glucose at all time points studied. Data are presented as mean percent change $+/$ - standard error from eight separate experiments $\left({ }^{* * *} p<\right.$ $0.0012 .8 \mathrm{mM}$ Glucose (control) vs S43126 [10 $\mathrm{MM}] \& 16.7 \mathrm{mM}$ Glucose at the same time, one-way ANOVA). 
Citation: Tesfai J, Crane L, Baziard-Mouysset G, Edwards LP (2012) Novel I-Imidazoline Agonist S43126 Augment Insulin Secretion in Min6 Cells. J Diabetes Metab 3:183. doi:10.4172/2155-6156.1000183

Page 5 of 7

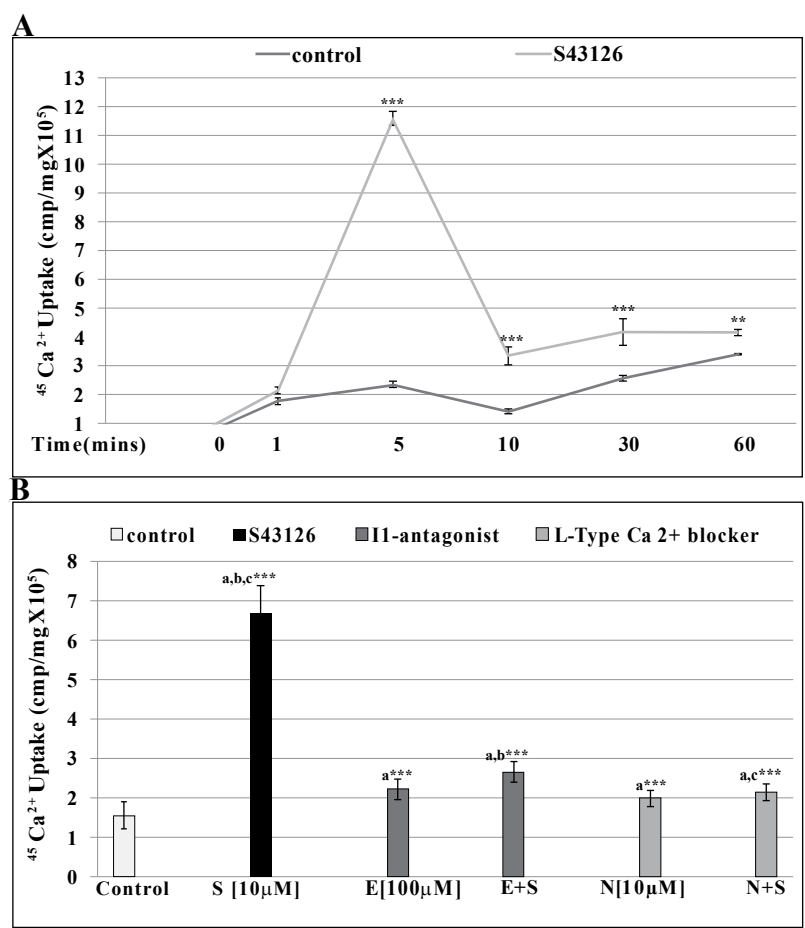

Figure 6: Effects of $\mathrm{S} 43126$ on ${ }^{45} \mathrm{Ca}^{2+}$ uptake. (A) $\mathrm{S} 43126\left[10^{-5} \mathrm{M}\right]$ induced a time-dependent increase in ${ }^{45} \mathrm{Ca}^{2+}$ influx up to $5 \mathrm{mins}$, followed by a decline at $10 \mathrm{~min}$ and then a plateau between $30-60$ mins. Data are presented as mean percent change $+/$ - standard error from four separate experiments run in duplicate. $\left({ }^{* * *} \mathrm{p}<0.001\right.$ Control vs $S 43126[10 \mu \mathrm{M}]$ at the same time, two-way ANOVA). (B) The ${ }^{45} \mathrm{Ca}^{2+}$ influx mediated by $\mathrm{S} 43126\left[10^{-5} \mathrm{M}\right]$ was attenuated in the presence of efaroxan [100 $\mu \mathrm{M}]$ and nifedipine [10 $\mu \mathrm{M}]$. The data are presented as mean percent change $+/-S$.E. from four separate experiments run in duplicate. $\left(a={ }^{* * *} p<0.001\right.$ Control vs $\mathbf{S}, \mathbf{E}, \mathbf{E}+\mathbf{S}, \mathbf{N}, \mathbf{N}+\mathbf{S}$, $\boldsymbol{b}={ }^{* * *} \mathrm{p}<0.001 \mathrm{E}$ vs $\mathbf{S}, \mathbf{E}+\mathbf{S}$ and $\boldsymbol{c}={ }^{* * *} \mathrm{p}<0.001 \mathrm{~N}$ vs $\mathbf{S}, \mathbf{N}+\mathbf{S}$, one-way ANOVA).

the peripheral glucose lowering effects of agmatine involved secretion of $\beta$-endorphins from the adrenal medulla, secondary to activation of adrenal $\mathrm{I}_{2}$-imidazoline receptors. $\beta$-endorphins are known to decrease the gene expression of phosphoenolpyruvate carboxykinase (PEPCK), a key enzyme in gluconeogenesis [9]. Increased GLUT4 gene expression was also involved in the glucose lowering effects of agmatine [9].

The novel compound $\mathrm{S} 4321$ has affinity at $\mathrm{I}_{2}$-imidazoline receptors, however it is unknown whether this agent acts as an agonist or antagonist at the $\mathrm{I}_{2}$-imidazoline receptors [22]. It is unlikely that the insulin release caused by $\mathrm{S} 43126$ was due to an action at $\mathrm{I}_{2}$-imidazoline receptors, since as stated above, agmatine which also has effects at $\mathrm{I}_{2}$ imidazoline receptors does not cause insulin release in normal rats. In addition, $\mathrm{I}_{2}$-ligands such as cirazoline and idazoxan were shown to cause insulin release from RIN-5AH insulinoma cell line, but not by their actions at $\mathrm{I}_{2}$-imidazoline receptors, since irreversible blockade of the $\mathrm{I}_{2}$-receptor by clorgyline did not attenuate the effects of these compounds on insulin secretion. The proposed mechanism for insulin release by these ligands was an action on $\mathrm{K}_{\mathrm{ATP}}$ channels [28].

Imidazoline compounds are not uniform in the mechanism by which they stimulate insulin release from pancreatic beta cells. Some imidazolines such as efaroxan [29,30], phentolamine [31] and RX871024 [32-33] stimulate insulin secretion both in vivo and in vitro by binding to $\mathrm{K}_{\mathrm{ATP}}$ channels [29-34]. The pore forming subunit of the $\mathrm{K}_{\text {ATP }}$ channel, Kir6.2 contains an imidazoline binding site [35] to
A

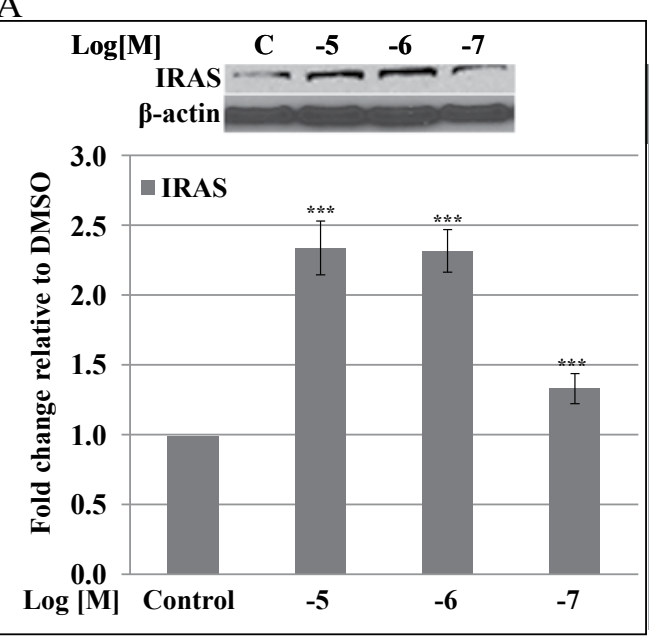

$\mathrm{B}$
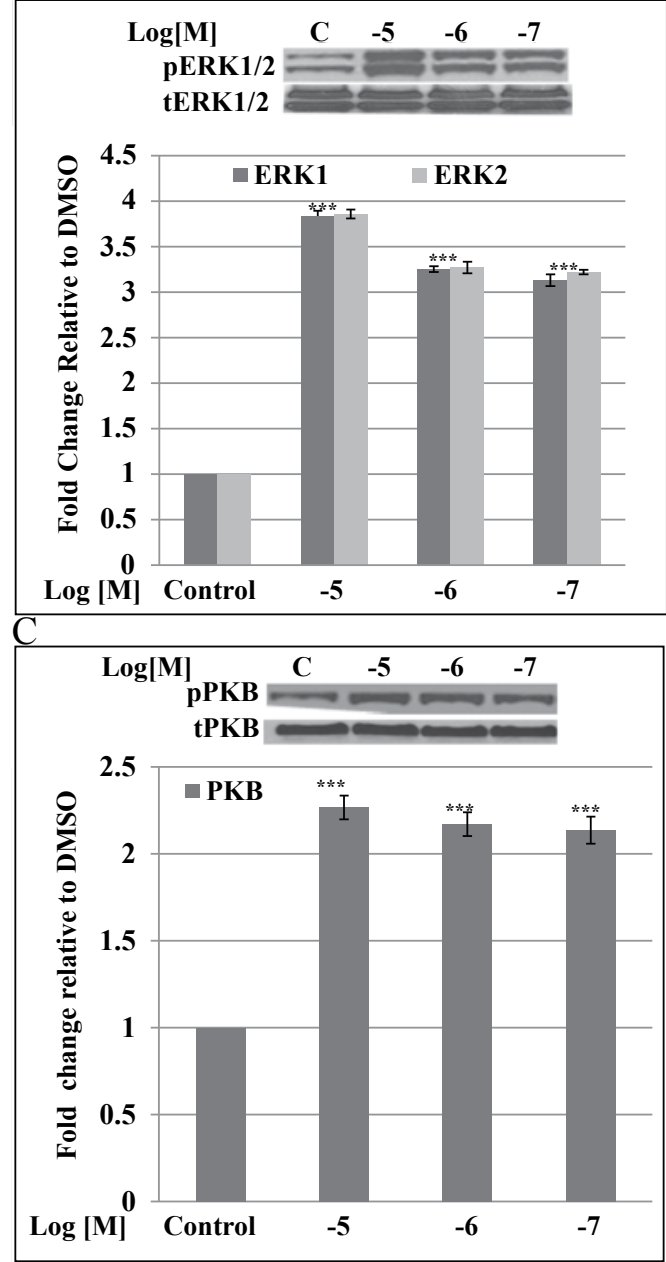

Figure 7: Dose-Response WB. Effects of S43126 $\left[10^{-7} 10^{-5} \mathrm{M}\right]$ on (A) IRAS protein expression (B) ERK1/2 phosphorylation (C) PKB (Akt) phosphorylation. S43126 $\left[10^{-7} 10^{-5} \mathrm{M}\right]$ caused an increased induction of IRAS protein, and a dose-dependent increase in the phosphorylation of both ERK1/2 and PKB. The relative protein expression of IRAS was defined by the ratio of the $\beta$-actin while the relative phosphorylation of ERK1/2 and PKB was defined by the ratio of phosphorylated active form to total immunoreactive protein, in arbitrary absorbance units. Data are presented as mean percent change $+/$ - standard error from two separate experiments run in duplicate. $\left({ }^{* * *} p<0.001\right.$ Control vs Dose [10-7 $\left.-10-5 \mathrm{M}\right]$, one-way ANOVA). 
which certain imidazolines bind, leading to membrane depolarization, activation of voltage-dependent calcium channels, and subsequent calcium influx, and insulin secretion. Some imidazolines such as BL11282 stimulate insulin secretion only at elevated levels of glucose and does not block the $\mathrm{K}_{\mathrm{ATP}}$ channel [18]. This property suggests that the risk of hypoglycemia would be very low in patients treated with BL11282. However, we are unaware of any published data suggesting that BL11282 lowers blood pressure. Thus BL11282 may not possess the utility that S43126 has in impacting both hypertension and insulin resistance.

S-21663 is an imidazoline compound that is a non glucosedependent insulin secretagogue, which does not readily induce hypoglycemia [15]. The authors explained the discrepancy between the ability of S-21663 to stimulate insulin secretion at all levels of glucose and the lack of hypoglycemia seen in vivo by the existence of some compensatory mode of action by this compound in vivo, but not seen in vitro. S-21663 acts in a manner that is dependent on calcium entry via L-type calcium channels that are activated by closure of non $\mathrm{K}_{\mathrm{ATP}}$ potassium channels [15]. Our novel compound S43126 also caused an increase in intracellular calcium via influx through nifedipine sensitive calcium channels. Unlike other imidazolines, we showed that the insulinotropic effect of $\$ 43126$ could be blocked by efaroxan, an $\mathrm{I}_{1}$-imidazoline antagonist. In addition to its antagonistic effect at $\mathrm{I}_{1}$-imidazoline sites, efaroxan can also interact with $\mathrm{K}_{\text {ATP }}$ channels or the $\mathrm{I}_{3}$-imidazoline receptor to cause insulin release. We observed that efaroxan did cause release of insulin presumably through its action at $\mathrm{K}_{\mathrm{ATP}}$ channels or the $\mathrm{I}_{3}$-imidazoline receptor. Combination of $\mathrm{S} 43126$ and efaroxan resulted in inhibition of insulin release; this suggested that at $100 \mu \mathrm{M}$, efaroxan acted as an effective blocker of the $\mathrm{I}_{1}$-receptor. The degree of antagonism caused by efaroxan was complicated by its ability to release insulin and a purer antagonist would prove more useful. The functional effects of S43126 at the various subytpes of imidazoline receptors need to be further studied, using inhibitors without intrinsic effects at these receptors.

S43126 also caused an increased induction of IRAS protein, and an increased phosphorylation of ERK and $\mathrm{PKB}$ which are components of the I-imidazoline signaling pathways. In one study, PKB function in beta cells was disrupted by expression of a kinase-dead dominant negative form of $\mathrm{PKB} \alpha$ (rip-kdpkb) and defective insulin secretion was observed, but no reduction in islet size [36]. This suggests that at least $\mathrm{PKBa}$ may play a role in insulin secretion. There is some controversy surrounding the exact role of different isoforms of $\mathrm{PKB}$ in the pancreas. Recent work by Buzzi et al. [37] showed that only PKBa but not PKB $\gamma$ or PKB $\beta$ is activated downstream of IRS2 in beta cells. Overexpression of PKBa by adenovirus caused an increased proliferation of beta cells, while overexpression of $\mathrm{PKB} \gamma$ and $\mathrm{PKB} \beta$ were ineffective. In another study, it was shown that $\mathrm{PKB} \alpha$-deficient mice can show enhanced glucose tolerance in addition to improved beta cell function and higher insulin sensitivity in adipocytes. Further studies will be needed to determine the importance of increased phosphorylation of $\mathrm{PKB}$ by $S 43126$ on insulin sensitivity, and any possible involvement of $I_{2}$ imidazoline receptors. These studies will need to consider the specific isoforms of $\mathrm{PKB}$, which, as the recent studies showed, may even have opposing effects [37]

In conclusion, S43126 is a novel compound that activated $\mathrm{I}_{1}$ imidazoline receptors but not $\alpha$-adrenoceptors $[23,38]$. We have shown that S43126 induced insulin secretion in a dose and time dependent manner. Because S43126 increased insulin release at higher glucose levels compared to basal condition, the risk of hypoglycemia associated with the use of $\$ 43126$ is diminished [9]. Thus, the present study showed that $\mathrm{S} 43126$ activated at least two distinct mechanisms to promote insulin release. One of these may involve binding to imidazoline $\mathrm{I}_{1}$-receptors, while a second arises from calcium influx due to L-type $\mathrm{Ca}^{2+}$ channels. More importantly, S41326 activated components of the $\mathrm{I}_{1}$-imidazoline signaling pathways, namely IRAS, ERK and PKB in Min6 $\beta$-cells have the potential to act as an insulin sensitizer. Imidazoline agonists should be developed as an innovative pharmacological approach for the management of Type II diabetes.

\section{Acknowledgements}

These studies were supported in part by NIH (1R15DK084468-01A1) and the Center for Health Disparities at Loma Linda University.

\section{References}

1. Hansen BC (1999) The Metabolic Syndrome X. Ann NY Acad Sci 892: 1-24

2. Bousquet P, Feldman J, Schwartz J (1984) Central cardiovascular effects of alpha adrenergic drugs: differences between catecholamines and imidazolines. J Pharmacol Exp Ther 230: 232-236.

3. Bousquet $P$ (1995) Imidazoline receptors: from basic concepts to recent developments. J Cardiovasc Pharmacol 26: S1-S6.

4. Brown CA, Chan SL, Stillings MR, Smith SA, Morgan NG (1993) Antagonism of the stimulatory effects of efaroxan and glibenclamide in rat pancreatic islets by the imidazoline, RX801080. Br J Pharmacol 110: 1017-1022.

5. Tonello R, Villarinho JG, da Silva Sant'anna G, Tamiozzo L, Machado P, et al. (2012) The potential antidepressant-like effect of imidazoline I2 ligand 2-BFI in mice. Prog Neuropsychopharmacol Biol Psychiatry 37:15-27.

6. Li JX, Zhang $Y(2012)$ Emerging drug targets for pain treatment. Eur $J$ Pharmacol 681: 1-5

Thorn DA, Zhang Y, Peng BW, Winter JC, Li JX (2011) Effects of imidazoline $\mathrm{I}_{2}$ receptor ligands on morphine- and tramadol-induced antinociception in rats. Eur J Pharmacol 670: 435-440.

8. Jou SB, Liu IM, Cheng JT (2004) Activation of imidazoline receptor by agmatine to lower plasma glucose in streptozotocin-induced diabetic rats. Neurosci Lett 358: $111-114$

9. Hwang SL, Liu IM, Tzeng TF, Cheng JT (2005) Activation of imidazoline receptors in adrenal gland to lower plasma glucose in streptozotocin-induced diabetic rats. Diabetologia 48: 767-775.

10. Ko WC, Liu IM, Chung HH, Cheng JT (2008) Activation of I(2)-imidazoline receptors may ameliorate insulin resistance in fructose-rich chow-fed rats. Neurosci Lett 448: 90-93.

11. Ernsberger P, Westbrooks KL, Christen MO, Schäfer SG (1992) A second generation of centrally acting antihypertensive agents act on putative $I_{1}$ imidazoline receptors. J Cardiovasc Pharmacol 20: S1-S10.

12. Ernsberger P Giuliano R, Willette RN, Reiss DJ (1990) Role of imidazole receptors in the vasodepressor response to clonidine analogs in the rostral ventrolateral medulla. J Pharmacol Exp Ther 253: 408-418.

13. De Luca N, Izzo R, Fontana D, lovino G, Argenziano L, et al. (2000) Haemodynamic and metabolic effects of rilmenidine in hypertensive patients with metabolic syndrome $X$. A double-blind parallel study versus amlodipine. $J$ Hypertens 18: 1515-1522.

14. Hansson L (1998) Therapy of hypertension and metabolic syndrome: today's standard and tomorrow's perspectives. Blood Press Suppl 3: 20-22.

15. Brigand LL, Virsolvy A, Peyrollier K, Manechez D, Godfroid JJ, et al. (1997) Stimulation of insulin Release from the Min6 Cell line by new imidazoline compound, S-21663: evidence for the exitance of a novel imidazoline site in $\beta$-cells. Br J Pharmacol 122: 786-791.

16. Mourtada M, Smith SA, Morgan NG (1998) Effector systems involved in the insulin secretory responses to efaroxan and RX871024 in rat islets of Langerhans. Eur J Pharmacol 350: 251-258.

17. Brigand LL, Virsolvy A, Manechez D, Godfroid JJ, Lematre BG, et al. (1999) In vitro mechanism of action on insulin release of $S-22068$, a new putative antidiabetic compound. Br J Pharmacol 128: 1021-1026. 
Citation: Tesfai J, Crane L, Baziard-Mouysset G, Edwards LP (2012) Novel I-Imidazoline Agonist S43126 Augment Insulin Secretion in Min6 Cells. J Diabetes Metab 3:183. doi:10.4172/2155-6156.1000183

Page 7 of 7

18. Efanov AM, Zaitsey SV, Mest HJ, Raap A, Appelskog IB, et al. (2001) The Novel Imidazoline Compound BL11282 Potentiates Glucose-Induce Insulin Secretion in Pancreatic $\beta$-Cells in the absence of Modulation of $\mathrm{K}_{\text {ATP }}$ Channel Activity. Diabetes 50: 797-802.

19. Olsen HL, Norby PL, Hoy M, Spee P, Thams $P$, et al. (2003) Imidazoline NNC770074 stimulates $\mathrm{Ca}^{2+}$-evoked exocytosis in INS-1E cells by a phospholipase $\mathrm{A}_{2}$-dependent mechanism. Biochem Biophys Res Commun 303: 1148-1151.

20. Proks $P$, Ashcroft FM (1997) Phentolamine block of KATP channels is mediated by Kir6.2. Proc Natl Acad Sci USA 94: 11716-11720.

21. Monks LK, Cosgrove KE, Dunne MJ, Ramsden CA, Morgan NG, et al. (1999) Affinity isolation of imidazoline binding protein from rat brain using 5-aminoefaroxan as ligand. FEBS Lett 447: 61-64.

22. Anastassiadou M, Danoun S, Crane L, Baziard-Mouysset G, Payard M, et al (2001) Synthesis and pharmacological evaluation of imidazoline sites I1 and I2 selective ligands. Bioorg Med Chem 9: 585-592.

23. Edwards LP, Crane L, Baziard-Mouysset G, Brown-Bryan T (2010) Imidazolines as single agent therapy for diabetics with hypertension, FASEB $J$ (Meeting Abstract Supplement) 597.3.

24. Schmid GM, Meda P, Caille D, Wargent E, O'Dowd J, et al. (2007) Inhibition of Insulin Secretion by Betagranin, an N-terminal Chromogranin A Fragment. J Biol Chem 282: 12717-12724

25. Edwards L, Hessinger DA (2000) Portuguese Man-of-war (Physalia physalis) venom induces calcium influx into cells by permeabilizing plasma membranes. Toxicon 38: 1015-1028

26. Brigand LL, Virsolvy A, Peyrollier K, Manechez D, Godfroid JJ, et al. (1997) Stimulation of insulin Release from the Min6 Cell line by new imidazoline compound, S-21663: evidence for the exitance of a novel imidazoline site in beta cells. Br J Pharmacol 122: 786-791.

27. Pfeiffer EF, Thum C, Raptis S, Beischer W, Ziegler R (1976) Hypoglycemia in diabetics. Horm Metab Res 6: 112-126.

28. Olmos G, Kulkarni RN, Haque M, MacDermot J (1994) Imidazolines stimulate release of insulin from RIN-5AH cells independently from imidazoline I1 and I2 receptors. Eur J Pharmacol 262: 41-48.

29. Chan SL, Morgan NG (1990) Stimulation of insulin secretion by efaroxan may involve interaction with potassium channels, Eur J Pharmacol 176:97-101

30. Chapman JC, McClenaghan NH, Cosgrove KE, Hashmi MN, Shepherd RM, et al. (1999) ATP-sensitive potassium channels and efaroxan-induced insulin release in the electrofusion derived BRIN-BD11 $\beta$-cell line. Diabetes 48: 2349 2357.

31. Schulz A, Hasselblatt A (1988) Phentolamine, a deceptive tool to investigate sympathetic nervous control of insulin release. Naunyn Schmiedebergs Arch Pharmacol 337: 637-643.

32. Mourtada M, Chan SLF, Smith SA, Morgan NG (1999) Multiple effector pathways regulate the insulin secretory response to the imidazoline RX871024 in isolated rat pancreatic islets. $\mathrm{Br} J$ Pharmacol 127: 1279-1287.

33. Efanov AM, Zaitsev SV, Efanova IB, Zhu S, Ostenson CG, et al. (1998) Signaling and sites of interaction for RX871024 and sulfonylurea in the stimulation of insulin release. Am J Physiol 274: E751-757

34. Chan SLF, Dunne MJ, Stillings MR, Morgan NG (1991. The a2-adrenoceptor antagonist efaroxan modulates $\mathrm{K}+\mathrm{ATP}$ channels in insulin secreting cells. Eur J Pharmacol 204: 41-48.

35. Proks $P$, Ashcroft FM (1997) Phentolamine block of KATP channels is mediated by Kir6.2. Proc Natl Acad Sci USA 94: 11716-11720.

36. Bernal-Mizrachi E, Fatrai S, Johnson JD, Ohsugi M, Otani K, et al. (2004) Defective insulin secretion and increased susceptibility to experimental diabetes are induced by reduced Akt activity in pancreatic islet beta cells. J Clin Invest 114: 928-936.

37. Buzzi F, Xu L, Zuellig RA, Boller SB, Spinas GA, et al. (2010) Differential effects of protein kinase B/Akt isoforms on glucose homeostasis and islet mass. Mol Cell Biol 30: 601-612

38. Tesfai J, Crane L, Mouysset GB, Kennedy W, Edwards LP (2011) Novel I1 Imidazoline S43126 Enhance Insulin Action in PC12 Cells. Pharmacol Rep 63: 1442-1449. 